http://kitaibelia.unideb.hu/

ISSN 2064-4507 (Online) • ISSN 1219-9672 (Print)

(C) 2015, Department of Botany, University of Debrecen, Hungary

21 (1): 55-62.; 2016

DOI: $10.17542 / 21.55$

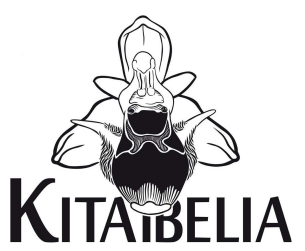

\title{
A villányi Somsich-hegy természeti értékei, a veszélyeztető tényezők és természetvédelmi teendők
}

\author{
TOLNAY DOLLY \\ MTA Ökológiai Kutatóközpont, Ökológiai és Botanikai Intézet, H-2163 Vácrátót, Alkotmány utca 2-4.; \\ tolnay.dolly@okologia.mta.hu

\section{Natural values of Mt Somsich near Villány, threatening factors and necessary conservation actions}

\begin{abstract}
Although Mt Somsich is very rich in natural values, it is still a poorly-known part of the Villány Mts. Apart from a few scattered floristic data and a short habitat description, its vegetation is virtually unexplored. The aim of this paper is to characterize the natural and semi-natural habitats of Mt Somsich, give the current population sizes of the protected plant species, survey their threats, and offer suggestions for further conservation activities. Disregarding the totally artificial habitats, five habitat types were distinguished on Mt Somsich, of which the pubescent oak scrub is the most valuable. A total of 15 protected plant species have been reported so far, of which 11 are currently recorded on Mt Somsich. The local wildlife is affected by loss and fragmentation of habitats as well as illegal activities. The negative influences cannot be fully eliminated, but could be minimized.
\end{abstract}

Keywords: floristics, habitat, protected plant species, Villány Mts

Összefoglaló - A Somsich-hegy a Villányi-hegység kevéssé ismert, ám lokálisan jelentős természeti értékekkel rendelkező tagja. Növényzetéről eddig mindössze néhány elszórt florisztikai adat és egy néhány soros jellemzés született. Jelen tanulmány célja a Somsich-hegy természetközeli élőhelyeinek jellemzése, az itt előforduló védett növények aktuális egyedszámának megadása, a természeti értékeket veszélyeztető tényezők összefoglalása, valamint javaslatok megfogalmazása a természetvédelmi problémák megoldására. A Somsich-hegyen (a teljesen mesterséges élőhelyeket leszámítva) öt élőhelytípust különítettem el, amelyek közül a karsztbokorerdő a legértékesebb. A területről eddig 15 védett növényfajt jeleztek, amelyek közül jelenleg 11 található itt meg. A természeti értékek fennmaradását veszélyeztető faktorok részben a kis kiterjedésből és az elszigeteltségből adódnak, részben illegális tevékenységekre vezethetők vissza. A kedvezőtlen hatások nem szüntethetők meg teljesen, mérséklésükre azonban van lehetőség.

Kulcsszavak: élőhely, florisztika, védett növények, Villányi-hegység

\section{Bevezetés és célkitűzés}

A Villányi-hegység florisztikai és vegetációtani szempontból alaposan kutatott kistáj (DÉNES 2000), de ez főleg a hegység központi részeire vonatkozik (Szársomlyó, Tenkes, Csukmahegy, Fekete-hegy). A kisebb magasságú nyugati és keleti peremi részek kevéssé kutatottak (ERDős et al. 2010). 
Ennek tudható be, hogy az utóbbi idôben több érdekes adat került elő a hegység korábban elhanyagolt részeiről. Így például a Szavai-hegyről a közelmúltban publikálták a Himantoglossum caprinum (M. Bieb.) Spreng. egy rendkívül jelentős állományát, számos más védett faj társaságában (ERDős et al. 2010, 2011). Szintén számos védett növény új előfordulási adata vált ismertté a csarnótai Nagy-hegyről (ERDős et al. 2011, BÁTORI et al. 2014). Mindez arra utal, hogy a kevéssé kutatott részek is tartogathatnak meglepetéseket, és természetvédelmileg fontosak lehetnek.

A Villány közelében található Somsich-hegy növényzetével csak NAGY és VöRöss (1967) tanulmánya foglalkozott. A későbbiekben mindössze néhány szórványos florisztikai adatot közöltek a területről (DÉNES 1996, BÁTORI et al. 2010, ERDős et al. 2010, 2013). A vegetációra vonatkozóan eddig csak egy néhány soros rövid jellemzés készült (ERDős et al. 2012).

Cikkem célkitűzése a Somsich-hegy természetközeli tetőrégiójának jellemzése. Elsőként összefoglalom a természeti adottságokról rendelkezésre álló ismereteket, majd jellemzem a tájtörténetét. Megadom a természetközeli élőhelyek térképét és rövid leírását. Ismételt terepbejárások alapján közlöm a védett növényfajok aktuális egyedszámát. Bemutatom a természeti értékeket veszélyeztető tényezőket és javaslatokat fogalmazok meg a kezelésre vonatkozóan. Cikkemmel szeretnék hozzájárulni a villányi Somsich-hegy természeti értékeinek jobb ismertségéhez és hatékonyabb megőrzéséhez.

\section{Anyag és módszer}

A Somsich-hegy tájtörténetére vonatkozó információkat helytörténeti dokumentumok és archív térképek segítségével gyűjtöttem össze.

2012 augusztusában terepbejárás során lehatároltam a növényzeti foltokat, amelyeket röviden jellemeztem. A foltok kis kiterjedése és degradált állapota miatt növénytársulásként való azonosításuk nehézségekbe ütközött, de ahol megoldható volt, ott a foltokhoz BoRHIDI (2003) alapján rendeltem növénytársulásokat. Az adatok digitalizálásával élőhelytérképet készítettem ArcView GIS 3.2 segítségével. 2012-től 2015-ig minden évben a vegetációs időszakban többször alapos terepbejárást végeztem florisztikai adatgyűjtés céljából, a védett fajokra koncentrálva, melynek során megbecsültem a védett fajok egyedszámát. A bejárások során felmértem a veszélyeztető tényezőket, majd javaslatokat fogalmaztam meg a természeti értékek hosszú távú megőrzésére vonatkozóan. A növényfajok megnevezésénél KIRÁLY (2009) nevezéktanához igazodtam.

\section{Természeti adottságok}

A Somsich-hegy a Dunántúl dél-keleti részén elhelyezkedő Villányi-hegység egyik legkeletibb tagja. Villánytól ÉNY-ra helyezkedik el (N45.87389, E18.44278º, magassága $185 \mathrm{~m} . \mathrm{Az}$ alapkőzet mészkő, amit a gerincközeli rész kivételével lösz borít, de a gerinc közelében a mészkősziklák a felszínen vagy annak közelében vannak. A talaj rendzina. Az évi középhőmérséklet $10,5{ }^{\circ} \mathrm{C}$, az átlagos évi csapadékmennyiség $660 \mathrm{~mm}$ (DövÉNYI 2010). A Somsich-hegy a Dél-Dunántúl (Praeillyricum) flóravidékének Sopianicum flórajárásába tartozik (BORHIDI \& SÁNTA 1999).

\section{Tájtörténet}

A Villányi-hegység tájhasználatát több száz éve a szőlőművelés határozza meg (ERDős 2016). Természetközeli növényzet csak a meredekebb, illetve a sziklás részeken maradhatott meg (ERDős et al. 2012). Kis magassága, a meredek lejtők hiánya és Villány közelsége miatt a Somsich-hegy fokozottan ki volt téve a mezőgazdaság hatásainak. Ennek következtében 
jelentős részét vélhetően már igen korán szőlőültetvényekkel telepítették be. A közeli dúlők elnevezései is szőlőművelésre utalnak (PESTI 1982). Maga a Somsich-hegy nevét egykori tulajdonosáról kapta (PESTI 1982).

A legkorábbi rendelkezésre álló térkép az első katonai felmérés során készült (17801784). Ezen a Somsich-hegy teljes területén szőlöültetvényeket jeleznek (HM HADTÖRTÉNETI INTÉZET ÉS MÚZEUM TÉRKÉPTÁRA 2004). Ennek ellenére kizártnak tekinthető, hogy a gerincközeli részt, ahol igen nagy mészkősziklák vannak a felszínen, és a vékony rendzina rendkívül köves, valaha művelésbe vonták volna. Azt, hogy a gerincrégió korábban nem állt művelés alatt, több XIX. századi térkép is megerősíti, amelyek a környező szőlőstelkektől jól elkülönülő, sziklás vagy növényzettel borított részt jeleznek itt (ANoNYMous 1847, 1853, 1857).

A Somsich-hegy gerincének nyugati részén az 1950-es évek első felében katonai bunkert építettek (ERDős 2016), amely azonban a jelenlegi természetközeli élőhelyeknek legfeljebb a nyugati csücskén okozhatott zavarást. A föld alatti bunker jelenleg is megvan, kis része a felszínen is látható.

NAGY és VöRöss (1967) szerint az 1960-as években a gerincközeli rész nem állt művelés alatt, sem legeltetés, sem kaszálás nem érintette, viszont tavasszal esetenként az avart felgyújtották. Ekkor már csak asszociáció-fragmentumokat említenek a területről.

A területet 2011-ben Villány Város Önkormányzata helyi jelentőségű védett természeti területté nyilvánította.

\section{A Somsich-hegy gerincközeli régiójának élőhelyei}

A továbbiakban röviden jellemzem a vizsgálati terület élőhelyeit (1. ábra).

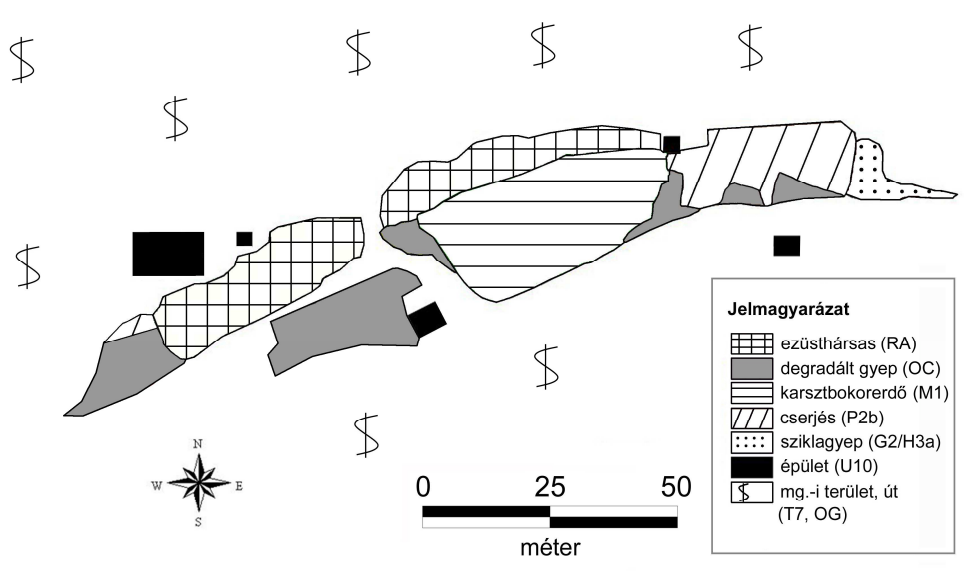

1. ábra. A Somsich-hegy élőhelyei

Fig. 1. Habitat types of Mt Somsich

Ezüsthársas: A nyugati részen idős Tilia tomentosa Moench egyedekből álló fasor, szegényes aljnövényzettel (Alliaria petiolata (M. Bieb.) Cavara et Grande, Anthriscus cerefolium (L.) Hoffm., Stellaria media (L.) Vill., Veronica hederifolia L.), egy tő Ruscus aculeatus L. előfordulásával. A keleti egység fiatal, sarj eredetű ezüsthársak keskeny sávja, ahol a Helleborus odorus Waldst. et Kit. nagyszámú előfordulása emelhető ki. Ezen faj, valamint a NAGY és VöRöss (1967) által jelzett, azóta feltehetően eltűnt fajok (Anemone ranunculoides L., Arum maculatum L., Carpinus betulus L., Melittis melissophyllum L.) alapján a 
hársas foltok egykori gyertyános-tölgyes (Asperulo taurinae-Carpinetum) maradványai lehetnek.

Karsztbokorerdő: Sziklák közül kibúvó, göcsörtös törzsű, alacsony növekedésű Quercus pubescens Willd. és Fraxinus ornus L. egyedek által dominált állomány. Cserjeszintjének jellemző faja a Prunus spinosa L. Gyepszintjében természetességre utaló fajok a Dictamnus albus L., a Lonicera caprifolium L., a Buglossoides purpurocaerulea (L.) I. M. Johnston, az Euphorbia epithymoides L., a Tanacetum corymbosum (L.) Sch. Bip. Bár több zavarásjelző faj is jelen van (pl. Amaranthus retroflexus L., Chenopodium album L., Convolvulus arvensis L., Juglans regia L.), fajkészlete és szerkezete alapján egyértelműen karsztbokorerdőként (Inulo spiraefoliae-Quercetum pubescentis) azonosítható. A Somsich-hegy legépebben fennmaradt, legértékesebb élőhelye.

Sziklagyep/lejtősztyepprét: Festuca dalmatica (Hack.) K. Richt. és Bothriochloa ischaemum (L.) Keng által dominált gyepfolt. Jellemző a Stachys recta L., Eryngium campestre L., Linaria genistifolia (L.) Mill. és az Iris variegata L. előfordulása. Társulástanilag a Sedo sopianae-Festucetum dalmaticae és a Cleistogeni-Festucetum rupicolae állományaihoz áll közel, de állapota a kis méret és az ismételt gyomirtózás miatt erősen leromlott. Az erős degradációt jelző növények többek között: Chenopodium album, Conyza canadensis (L.) Cronquist, Setaria sp., de zavarásra utal a Bothriochloa ischaemum nagy tömegessége is.

Cserjés: Részben őshonos fásszárúak (Fraxinus ornus, Ligustrum vulgare L., Rosa canina L., Quercus pubescens), részben telepített növényzet (Mahonia aquifolium (Pursh) Nutt., Syringa vulgaris L., gyümölcsfák) által uralt állomány. Aljnövényzetében még fellelhetők az alábbi természetességre utaló fajok: Asplenium javorkaeanum Vida, Ruscus aculeatus, Dianthus giganteiformis Borbás s. str., Iris variegata, Buglossoides purpurocaerulea, Teucrium chamaedrys L., Melica ciliata L.

Degradált gyepfoltok: Túlnyomórészt zavarásra utaló fajok dominálta foltok (Elymus repens (L.) Gould, Arrhenatherum elatius (L.) P. Beauv. ex J. Presl et C. Presl, Dactylis glomerata L., Bothriochloa ischaemum, Muscari comosum (L.) Mill., Sedum rupestre L. s. l.). A természetességre utaló fajok egyértelműen alárendelt szerepet játszanak (pl. Carex praecox Schreb., Bromus inermis Leyss., Cleistogenes serotina (L.) Keng, Veronica spicata, Stachys recta L., Teucrium chamaedrys). Említésre érdemes a Dianthus giganteiformis és a Convolvulus cantabrica L. előfordulása, valamint a karsztbokorerdőt keletről szegélyező gyepfolt jelentős Muscari botryoides (L.) Mill. állománya.

\section{A védett növényfajok aktuális egyedszáma és előfordulása}

A szakirodalmi adatok (NAGY \& VöRÖSS 1967, BÁTORI et al. 2010, ERDős et al. 2010) alapján eddig összesen 15 védett faj előfordulását jelezték a Somsich-hegyről. Ezek aktuális egyedszámát és előfordulási helyeit, ismételt terepbejárásaim és számlálásaim alapján az alábbiakban közlöm.

Asplenium javorkaeanum Vida - 1 tő (a cserjésben).

Dianthus giganteiformis Borbás s. str. - 53 tő (a degradált gyepfoltokban és a cserjésben).

Helleborus odorus Waldst. et Kit. - 32 tő (az ezüsthársasban és a karsztbokorerdőben).

Sempervivum tectorum L. - 5 tő (a sziklagyepben).

Pisum elatius Steven - feltehetően eltűnt.

Dictamnus albus L. -60 tő (a karsztbokorerdőben).

Convolvulus cantabrica L. - 1 tő (degradált gyepben).

Lonicera caprifolium L. - 50 tő (a karsztbokorerdőben és az ezüsthársasban).

Aster amellus L. - feltehetően eltűnt.

Muscari botryoides (L.) Mill. - kb. 1000 tő (degradált gyepben). 
Allium sphaerocephalon L. - feltehetően eltűnt.

Ruscus aculeatus L. - 5 tő (a cserjésben, az ezüsthársasban és a karsztbokorerdőben).

Iris variegata L. - 90 tő (a degradált gyepfoltokban, a karsztbokorerdőben, a cserjésben és a sziklagyepben).

Festuca dalmatica (Hack.) K. Richt. - 110 tő (a másodlagos gyepben és a sziklagyepben).

Anacamptis pyramidalis (L.) Rich. - eltűnt, utoljára 2009-ben volt látható.

\section{Tájképi és zoológiai értékek}

A szőlőtermesztés által uralt tájban a fasorok, facsoportok, cserjések különleges jelentőségűek, részben mert megtörik a táj egyhangúságát, részben mert hozzájárulnak a levegő és a talajvíz minőségének javításához (RYSZKOWSKI 1992). A Villány fölé magasodó Somsich-hegy esetében a fás növényzet különös jelentőségű, megőrzése ebből a szempontból is indokolt.

Kis kiterjedése ellenére a Somsich-hegy természetközeli élőhelyeiben több védett állatfaj is előfordul, így a Mantis religiosa, Iphiclides podalirius, Dorcus parallelipipedus, Bufo viridis, Rana dalmatina, Natrix natrix, Erinaceus concolor.

\section{Veszélyeztető tényezők}

A természetközeli foltok kis kiterjedése: A Somsich-hegy esetében az egyik legnyilvánvalóbb veszélyeztető tényező a kis kiterjedés, ami (a degradációval együtt hatva) kis populációméreteket eredményez, melyek fokozottan ki vannak téve a lokális kihalásnak (STANDOVÁR \& PRIMACK 2001). Vélhetően ennek tudható be, hogy az utóbbi évtizedekben több értékes növényfaj eltűnt, mások előfordulása bizonytalanná vált a területen.

Elszigeteltség: A Somsich-hegy nagyon messze található a természetközeli élőhelyektől. A Szársomlyótól való távolsága kb. 2,5 km, a Fekete-hegytől mintegy 3,5km, a Templomhegytől kb. 0,6 km választja el. A Somsich-hegy természetközeli részeit intenzív művelés alatt álló mezőgazdasági területek szinte teljesen elszigetelik.

Hosszúkás alak: A Somsich-hegy védelem alatt álló gerincrégiója hosszúkás, elnyúlt alakú terület, így a szegélyhatás lényegében a teljes védett területet érinti (KERÉNYI 2007). A kedvezőtlen alak fokozottan érzékennyé tesz a szomszédos területeken folyó vegyszeres műveléssel szemben is.

Favágás: A védetté nyilvánításig a Somsich-hegy ezüsthársas és karsztbokorerdő foltjaiban az egyik legsúlyosabb veszélyeztető tényező a fák kivágása volt, ami a Somsichhegy eljellegtelenedésével, a tájképi érték csökkenésével, megnövekedett erózióval, valamint további természeti értékek eltűnésével fenyegetett. A védetté nyilvánítás óta újabb favágás nem történt.

Hulladéklerakás: A hulladék lerakása (építési törmelék, betonoszlopok, venyige) és a szemetelés minden élőhelytípusban problémát jelent. A védetté nyilvánítás óta az illegális hulladéklerakás problémája mérséklődött, és a felgyülemlett hulladék egy részének elszállítására is sor került.

Égetés: A Somsich-hegy sziklagyep foltját többször leégették. A védetté nyilvánítás óta nincs tudomásom újabb égetésről.

Gyomirtózás: A Somsich-hegyet mezőgazdasági területek veszik körül, így elkerülhetetlen a vegyszerek hatása. Elhelyezkedéséből adódóan a probléma a sziklagyepet érinti legjobban, melynek állapota az utóbbi néhány év során jelentősen leromlott (természetességre utaló fajok eltűnése vagy megritkulása, gyomok, zavarásjelző fajok és idegenhonos fajok elszaporodása). 
Taposás: A területen áthaladó utak mellett a taposás (járművek parkolása és fordulása) érinti a jelentős epergyöngyike-populációnak élőhelyet adó degradált gyepet.

Idegenhonos és ültetett fajok: A területre gyümölcsfákat, főként meggyfákat (Cerasus vulgaris Mill.) ültettek, illetve spontán terjedésük is tapasztalható. Ezek gátolják a természetes növényzet helyreállását, a növénytársulások jellegét alapvetően megváltoztatják. Az ültetett fajok közül kisebb problémát okoz a dió (Juglans regia) és az orgona (Syringa vulgaris L.) jelenléte. Az idegenhonos fajok közül említésre méltó a kövi varjúháj (Sedum rupestre L.) és a betyárkóró (Conyza canadensis).

\section{Javasolt természetvédelmi teendők}

Hulladék elszállítása: a védetté nyilvánítás óta sor került az építési törmelék és egyéb hulladék egy részének elszállítására. A további hulladék elszállítása sürgető feladat.

Favágás, égetés, hulladéklerakás elleni fellépés: a szomszédos szőlőstelkek tulajdonosai értesültek a védetté nyilvánításról, figyelmüket felhívták arra, hogy tartózkodjanak a fenti tevékenységektől. A favágás, az aljnövényzet égetése és a hulladéklerakás azóta mérséklődött, de továbbra is szükséges a rendszeres ellenőrzés, szükség esetén az illegális tevékenység elleni fellépés. Javasolható, hogy közterület-felügyelő rendszeresen tartson ellenőrzést a Somsich-hegyen.

Épületrom bontása, kutatógödör feltöltése: a Somsich-hegy védett részén egy leromlott állapotú, használaton kívüli présház áll. Az épület a növénytársulások közé nem illeszkedik, jelenléte a védett területtől idegen, a természeteshez hasonló állapotok helyreállítását akadályozza, ezért javasolható a lebontása, mely jelentősen növelné a védett terület természeti, esztétikai és turisztikai értékét. A védett területen található egy geológiai kutatógödör is, amelyet a tájba nem illeszkedő betonlappal fedtek be; indokolt volna a jelenlegi állapot megszüntetése.

Természetes regeneráció: egy terület védettsége, viszonylagos érintetlenségének biztosítása már önmagában is eredményezheti a természeti állapot bizonyos szintú javulását. Bár a Somsich-hegy esetében a spontán regeneráció rendkívül korlátozott mértékben vehető számításba, ennek ellenére itt is számítani lehet a természetes folyamatok általi spontán regenerációra. Így például egyes kivágott fák, cserjék újra kihajtanak. Az ezüsthárs (Tilia tomentosa) és a virágos kőris (Fraxinus ornus) jól sarjad és viszonylag gyorsan is nő. A molyhos tölgy (Quercus pubescens) kivágott egyedei viszont lényegesen lassabban pótlódnak. Az újulat a Somsich-hegyen jelen van, de a lassú növekedés miatt hosszú érintetlen időszakot kellene biztosítani ennek a fának.

Nemkívánatos fajok visszaszorítása: A területre gyümölcsfákat, fóként meggyfákat ültettek, illetve spontán terjedésük is tapasztalható. Ezek gátolják a természetes növényzet helyreállását, a növénytársulások jellegét alapvetően megváltoztatják. Szükséges lenne ezért visszaszorításuk.

Betelepítés: A Somsich-hegy nagyon messze van a természetközeli élőhelyektől, amelyektől szinte teljesen elszigetelődött, ezért a legtöbb olyan növényfaj, amely feltehetően eltűnt a Somsich-hegyről, saját magától már nem tud visszatelepülni. Fölmerülhet a védett vagy természetvédelmi szempontból értékes fajok visszatelepítése. Fontos kiemelni, hogy csak azon fajok visszatelepítése elfogadható, amelyek korábbi előfordulása botanikai kutatások alapján igazolt; itt Nagy és Vöröss (1967) dolgozatára lehet támaszkodni. Törekedni kell arra, hogy a lehető legközelebbi helyről történjen a visszatelepítés, mert a genetikai állomány ahhoz a leghasonlóbb. Visszatelepítési javaslataimat az első táblázatban foglaltam össze. 
1. táblázat. A Somsich-hegyre potenciálisan visszatelepíthető, eltűnt, bizonytalan előfordulású és ritka fajok, javasolt forrásterülettel (zárójelben alternatív forrásterülettel) és célterülettel (a védett fajok félkövérrel szedve)

Table 1. Extinct, doubtfully present and rare species deserving consideration for potential reintroduction to Mt Somsich, with suggested source areas (alternative source areas in parentheses) and target areas (protected species are highlighted in bold)

\begin{tabular}{|c|c|c|c|}
\hline & Betelepítendő faj & Forrásterület & $\begin{array}{c}\text { Célterület } \\
\text { a Somsich-hegyen }\end{array}$ \\
\hline \multirow{8}{*}{ 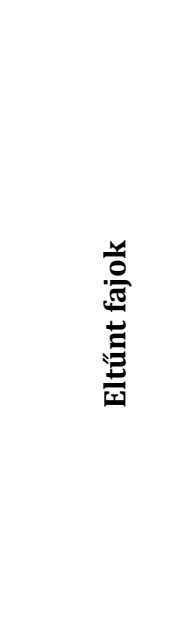 } & Anemone ranunculoides & Templom-hegy & ezüsthársas \\
\hline & Pisum elatius & Szársomlyó & karsztbokorerdő \\
\hline & Melittis melissophillum & $\begin{array}{l}\text { Átai-hegy, } \\
\text { Császár-hegy }\end{array}$ & ezüsthársas \\
\hline & Aster linosyris & $\begin{array}{l}\text { Fekete-hegy, } \\
\text { (Hosszú-hát), } \\
\text { (Szavai-hegy) }\end{array}$ & $\begin{array}{c}\text { sziklagyep, } \\
\text { másodlagos gyep }\end{array}$ \\
\hline & Aster amellus & Csukma & másodlagos gyep, sziklagyep \\
\hline & Artemisia alba & Szársomlyó (Tenkes) & $\begin{array}{c}\text { sziklagyep, } \\
\text { másodlagos gyep }\end{array}$ \\
\hline & Allium sphaerocephalon & Szársomlyó & $\begin{array}{c}\text { sziklagyep, } \\
\text { másodlagos gyep }\end{array}$ \\
\hline & Arum maculatum & Templom-hegy & ezüsthársas \\
\hline \multirow{3}{*}{ 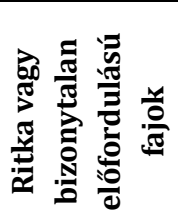 } & Convolvulus cantabrica & Szársomlyó (Csukma) & $\begin{array}{l}\text { sziklagyep, bokorerdő, } \\
\text { másodlagos gyep }\end{array}$ \\
\hline & Ruscus aculeatus & Villány, belterület & karsztbokorerdő, ezüsthársas \\
\hline & Anacamptis pyramidalis & Szársomlyó & sziklagyep \\
\hline
\end{tabular}

Bemutatás: szükséges lenne (és minimális költséggel megvalósítható volna) szöveges és képes tájékoztató táblák kihelyezése, amelyek röviden ismertetnék a Somsich-hegy értékeit, egyben felhívnák a figyelmet a védettségre.

\section{Konklúzió}

A villányi Somsich-hegy kis területe és a település közelsége ellenére helyi szinten jelentős természeti és tájképi értékekkel rendelkezik. Eddig 15 védett növényfaj előfordulását mutatták ki a területről, ezek közül 11 faj jelenleg is előfordul itt, bár néhányuk rendkívül alacsony egyedszámmal. A jogi védettség a természeti állapotokra kedvezőtlen hatásokat mérsékelte, de további lépések szükségesek a Somsich-hegy természeti értékeinek hosszabbtávú megőrzéséhez. A kis kiterjedésből és elszigeteltségből eredő természetvédelmi gondok megszüntetésére nincs lehetőség, ám a kellő körültekintéssel (és viszonylag alacsony költségekkel) megvalósítandó beavatkozások hozzájárulhatnak e kicsiny helyi jelentőségű védett terület természeti értékeinek megőrzéséhez. 


\section{Irodalom}

ANONYMous (1847): Villány helység határának térképe. BML BIV 981

Anonymous (1853): Croquis über die Ried- und Culturenweise-Vermessung der Gemeinde Villány. BML BmK 672.

ANONYMous (1857): Villány am 1ten September 1857. BML BIK 1008

BÁToRi Z., BoCK Cs. \& ERDős L. (2010): Florisztikai adatok a Dél-Dunántúlról. - Kitaibelia 15: 95-100.

BÁtori Z., ERdős L., CSEH V., TölgYesi Cs. \& ARADi E. (2014): Adatok Magyarország flórájához és vegetációjához I. - Kitaibelia 19: 89-104.

BoRHIDI A. (2003): Magyarország növénytársulásai. - Akadémiai Kiadó, Budapest, 610 pp.

Borhidi A. \& SÁNTA A. (szerk.) (1999): Vörös könyv Magyarország növénytársulásairól 1., 2. TermészetBúvár Alapítvány Kiadó, Budapest, 362 pp., 404 pp.

DÉnEs A. (1996): Adatok a Villányi-hegység flórájához. - A Janus Pannonius Múzeum Évkönyve 40: 5-8.

DÉNES A. (2000): A Villányi-hegység flóra- és vegetációkutatásának története, eredményeinek összefoglalása, különös tekintettel a védett és ritka fajok előfordulására. - Dunántúli Dolgozatok Természettudományi Sorozat 10: 47-77.

DöVÉNYI Z. (szerk.) (2010): Magyarország kistájainak katasztere, második kiadás. - MTA Földrajztudományi Kutatóintézet, Budapest, 876 pp.

ERDős L., CSEH, V. \& BÁTORI, Z. (2013): New localities of protected and rare plants in southern Hungary. Tiscia 39: 17-21.

ERdős L., DÉNES A., KovÁcs Gy., TóTH V. \& PÁL R. (2010): Adatok a Villányi-hegység flórájának ismeretéhez. - Botanikai Közlemények 97: 97-112.

ERdős L., DÉNes A., MorschHAuSER T., BÁTORI Z., TóTh V. \& KöRmöCzi L. (2012): A Villányi-hegység aktuális vegetációja észak-déli irányú vegetációs grádiensek tükrében. - Botanikai Közlemények 99: 47-63.

ERdős L., TolnaY D. \& TótH V. (2011): Kiegészítések a Villányi-hegység flórájához. - Botanikai Közlemények 98: 117-128.

ERDős Z. (2016): Villány története a kezdetektől 1990-ig. - Pannon Kultúra Alapítvány, Pécs, 358 pp.

HM HADTÖRTÉNETI INTÉZET ÉS MÚZEUM TÉRKÉPTÁRA (2004): Az első katonai felmérés. DVD-ROM. Budapest.

KERÉNYI A. (2007): Tájvédelem. - Pedellus Tankönyvkiadó, Debrecen, 184 pp.

KIRÁLY G. (szerk.) (2009): Új magyar füvészkönyv. - Aggteleki Nemzeti Park Igazgatóság, Jósvafő, 616 pp.

NAGY I. \& Vöröss L. Zs. (1967): A villányi Somsich-hegy növényzete. - A Pécsi Tanárképző Főiskola Tudományos Közleményei 1967: 3-15.

PESTI J. (szerk.) (1982): Baranya megye földrajzi nevei II. kötet. - Baranya Megyei Levéltár, Pécs, 1055 pp.

RYSZKOWSKI L. (1992): Energy and nutrient flows across boundaries in agricultural landscapes. - In: HANSEn A. J. \& Di CASTRI F. (eds), Landscape Boundaries. Consequences for Biotic Diversity and Ecological Flows, Springer-Verlag, New York, pp. 360-378.

StandovÁr T. \& Primack R. B. (2001): A természetvédelmi biológia alapjai. - Nemzeti Tankönyvkiadó, Budapest, 542 pp.

Beérkezett / received: 2016. 03. 09. • Elfogadva / accepted: 2016. 05. 07. 